\title{
Hubungan antara Kadar Zink Plasma dengan Gangguan Pemusatan Perhatian/Hiperaktivitas (GPP/H)
}

\author{
Sir Panggung T.S, Retno Sutomo, Amalia Setyati \\ Bagian Ilmu Kesehatan Anak Fakultas Kedokteran Universitas Gadjah Mada/RSUP Dr. Sardjito, Yogyakarta
}

\begin{abstract}
Latar belakang. Gangguan pemusatan perhatian/hiperaktivitas $(\mathrm{GPP} / \mathrm{H})$ atau attention deficit/ hyperactivity disorder (ADHD) merupakan gangguan neuro-behavioral yang paling sering pada anak dengan dampak besar bagi individu dan masyarakat. Prevalensi GPP/H di Indonesia 0,4\% - 26,2\%. Penelitian di berbagai negara menunjukkan keterlibatan zink dalam etiologi dan terapi GPP/H. Belum didapatkan data mengenai hubungan antara kadar zink plasma dengan GPP/H pada anak di Indonesia. Tujuan. Mengetahui hubungan antara kadar zink plasma dengan GPP/H pada anak.

Metode. Penelitian kasus kontrol dilaksanakan di RSUP Dr. Sardjito dan Pusat Pengkajian dan Pengamatan Tumbuh Kembang Anak (P3TKA) Yogyakarta pada Desember 2010-Maret 2011. Subyek adalah adalah 69 anak berusia 3-18 tahun, 34 anak dengan GPP/H dan 35 kontrol. Kadar zink plasma diperiksa dari sampel darah vena menggunakan metode atomic absorbance spectrophotometry (AAS). Analisis statisik menggunakan analisis deskriptif dan analisis bivariat dengan uji Chi-square terhadap perbedaan proporsi defisiensi zink antara kelompok kasus dan kontrol.

Hasil. Proporsi defisiensi zink pada anak yang menderita GPP/H lebih tinggi dibandingkan anak yang tidak menderita GPP/H, dengan nilai $\mathrm{p}=\mathbf{0 , 0 2 8}$, OR sebesar 8,8 (IK95\% antara 1,02-76,07).

Kesimpulan. Proporsi defisiensi zink pada anak yang menderita GPP/H lebih tinggi dibandingkan anak yang tidak menderita GPP/H, zink kemungkinan mempunyai peran dalam kejadian GPP/H. Sari Pediatri 2015;17(3):205-9.
\end{abstract}

Kata kunci: gangguan pemusatan perhatian/hiperaktivitas, attention deficit/ hyperactivity disorder, zink

\section{The Relationship between Plasma Zinc Level and Attention Deficit Hyperactivity Disorder}

Sir Panggung T.S, Retno Sutomo, Amalia Setyati

Background. Attention deficit / hyperactivity disorder (ADHD) is the most common neurobehavioral disorder in children with major impact for individual and community. The prevalence of ADHD in Indonesia is between 0,4 to 26,2\%. Several studies in different countries have shown the involvement of zinc in the etiology and treatment of ADHD. There was no data available about the relationship between plasma zinc level and children with ADHD in Indonesia.

Objective. To determine the relationship between plasma zinc levels with ADHD in children.

Methods. A case-control study was conducted at Sardjito General Hospital Yogyakarta and Assessment Centre for Child Development from December 2010 through March 2011. The subjects were 69 children aged 3-18 years, 34 children with ADHD and 35 controls. Plasma zinc levels examination was conducted from venous blood samples using the of atomic absorbance spectrophotometry (AAS) method. Chi-square test was utilized for statistical analysis with descriptive analysis and bivariate analysis for the differences in the proportion of zinc deficiency among case and control groups..

Results. The proportion of zinc deficiency was higher in children with ADHD compared to children who did not suffer from ADHD, with $p$ value $=0.028$ odds ratio 8.8 (CI 95\% 1.02 to 76.07$)$.

Conclusion. The proportion of zinc deficiency was higher in children with ADHD, zinc may play a role in ADHD.

Sari Pediatri 2015;17(3):205-9.

Keywords: attention deficit / hyperactivity disorder (ADHD), zinc

Alamat korespondensi: Dr. Sir Panggung T.S. Bagian Ilmu Kesehatan Anak FK UGM/ SMF Kesehatan Anak RSUP Dr. Sardjito Yogyakarta, Jl. Kesehatan No. 1, Yogyakarta 55284. Tel +62 274 561616, +62 274587333 ext 543. E-mail: sirpanggung97@gmail.com 


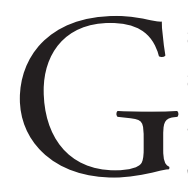

angguan pemusatan perhatian/hiperaktivitas $(\mathrm{GPP} / \mathrm{H})$ atau attention deficit/ hyperactivity disorder (ADHD) adalah salah satu gangguan neurobehavioral yang paling sering terjadi pada anak dan merupakan salah satu kondisi kesehatan kronik yang sering dialami anak usia sekolah. ${ }^{1}$ Gangguan pemusatan perhatian/ hiperaktivitas mempunyai dampak yang besar baik bagi individu maupun masyarakat. Dampak ini meliputi berbagai aspek antara lain biaya kesehatan, stres dalam keluarga, akademik-vokasional dan terhadap rasa harga diri (self esteem) individu. ${ }^{2}$

Prevalensi GPP/H di Indonesia antara 0,4\% sampai dengan $26,2 \%{ }^{3,4}$ Rasio laki-laki dibandingkan perempuan bervariasi antara 2:1 hingga 9:1. ${ }^{5}$ Berbagai penelitian menunjukkan bahwa nutrisi berperan dalam etiologi dan terapi GPP/H, salah satunya adalah zink. Zink merupakan mikronutrien esensial untuk perkembangan dan fungsi sistem saraf pusat. Zink diduga mempunyai hubungan dengan GPP/H melalui keterlibatan zink dalam pembentukan dan pengaturan melatonin yang mengatur fungsi dopamin. ${ }^{6-9}$

Penelitian yang dilakukan di beberapa negara menunjukkan hasil yang konsisten mengenai hubungan antara zink dengan GPP/H. Didapatkan bukti bahwa kadar zink pada anak dengan GPP/H lebih rendah dibandingkan kontrol. ${ }^{9-13}$ Disamping itu, didapatkan juga adanya hubungan negatif antara kadar zink dengan keparahan gejala GPP/H, dengan kadar zink yang lebih rendah mempunyai gejala GPP/H yang lebih berat. ${ }^{14}$

Sebuah studi menunjukkan pemberian zink sebagai terapi tambahan metilfenidat memberikan perbaikan gejala GPP/H yang lebih bermakna dibandingkan dengan yang mendapatkan terapi metilfenidat saja. ${ }^{15}$ Pemberian suplementasi tunggal dengan zink pada anak GPP/H menyebabkan penurunan keparahan gejala yang bermakna dibandingkan dengan plasebo. ${ }^{16}$

Dalam etiologi maupun terapi GPP/H, keterlibatan zink apabila terbukti dapat menjadi alternatif terapi yang murah, relatif aman, mempunyai efek samping minimal, dan dapat digunakan sebagai terapi pendamping dalam pengelolaan pasien $\mathrm{GPP} / \mathrm{H}$. Hal ini memberikan harapan baru mengingat GPP/H merupakan kondisi kesehatan yang kronis yang memerlukan pengelolaan jangka panjang dengan biaya yang mahal. ${ }^{14}$

\section{Metode}

Penelitian dilakukan pada bulan Desember 2010 sampai besar sampel terpenuhi dengan ijin dari Komisi Etik Penelitian FK UGM. Penelitian dilakukan di Klinik Tumbuh Kembang Anak RSUP Dr. Sardjito dan Pusat Pengkajian dan Pengamatan Tumbuh Kembang Anak (P3TKA) Yogyakarta untuk pengambilan kasus serta Sekolah Dasar (SD) Tegal Harjo, Depok, Sleman Yogyakarta untuk pengambilan kontrol. Desain penelitian adalah kasus kontrol (case control).

Kriteria inklusi kasus adalah anak umur 3-18 tahun, terdiagnosis GPP/H berdasarkan kriteria diagnosis DSM-IV, berdomisili di Daerah Istimewa Yogyakarta (DIY) dan bersedia mengikuti penelitian dengan menandatangani informed concent. Kriteria inklusi kontrol adalah anak umur 3-18 tahun, tidak menderita GPP/H berdasarkan kriteria diagnosis DSM-IV, bertempat tinggal di DIY dan bersedia mengikuti penelitian dengan menandatangani informed concent. Sebaliknya, kriteria ekskusi adalah anak yang menderita gizi buruk, menderita penyakit akut, menderita diare dalam 2 minggu sebelumnya, menderita penyakit kronis misalnya TB, penyakit ginjal, penyakit jantung, kelainan darah dan keganasan atau mengonsumsi zink lebih dari atau sama dengan $10 \mathrm{mg} /$ hari selama 4 bulan berturut-turut.

Penegakan diagnosis GPP/H dilakukan oleh dokter spesialis anak dengan minat tumbuh kembang, dokter spesialis anak sub bagian neurologi anak atau dokter spesialis kesehatan jiwa sub bagian psikiatri anak bersama dengan psikologi klinis anak.

Data penelitian didapatkan dari rekam medis, pengisian kuisioner, dan pemeriksaan kadar zink palsma. Pemeriksaan kadar zink plasma dilakukan di laboratorium Biokimia Fakultas Kedokteran Universitas Gadjah Mada dengan menggunakan metode atomic absorbance sphectrophotometry (AAS) dari 3 cc sampel darah vena yang diambil oleh petugas laboratorium yang terlatih. Hasil pemeriksaan ditunjukkan dengan terlihatnya angka pada spektrofotometer. Data kadar zink kemudian dibagi menjadi dua kategori, yaitu kadar zink rendah jika kadarnya kurang dari $70 \mu \mathrm{g} /$ dL dan normal jika lebih dari atau sama dengan 70 $\mu \mathrm{g} / \mathrm{dL}$.

Analisis menggunakan analisis deskriptif untuk menampilkan karakteristik subyek penelitian dan analisis bivariat menggunakan uji chi-square atau dengan Fisher's exact test apabila syarat uji chi-square 
tidak terpenuhi terhadap perbedaan proporsi defisiensi zink antara kelompok kasus dan kontrol.

Penentuan subyek penelitian dilakukan secara non probability sampling menggunakan consequtive sampling. Anak yang orang tuanya bersedia mengikuti penelitian dimasukkan dalam kelompok penelitian setelah melalui kriteria inklusi dan eksklusi. Besar sampel ditentukan berdasarkan perbedaan proporsi antara dua kelompok yang tidak berpasangan dan didapatkan besar sampel minimal 33 orang untuk masing-masing kelompok.

\section{Hasil}

Subyek penelitian terdiri atas kelompok kasus sejumlah 34 anak pasien GPP/H dan kelompok kontrol 35 anak yang tidak menderita GPP/H yang memenuhi kriteria inklusi dan ekslusi.

Kasus GPP/H didapatkan dari daftar pasien GPP/H bulan Januari 2004 hingga Desember 2010 yang berdasarkan rekam medis tidak mengalami gangguan lain selain GPP/H, 76 pasien dari Klinik Tumbuh
Kembang Anak RSUP Dr. Sardjito dan 70 pasien dari P3TKA Yogyakarta yang kemudian dihubungi melalui telepon dan/atau surat. Pasien GPP/H yang orang tua/ wali bersedia mengikuti penelitian kemudian diundang ke RSUP Dr. Sardjito untuk dilakukan pengambilan sampel darah dan pengisian kuisioner.

Tigapuluh delapan pasien GPP/H orangtuanya bersedia mengikuti penelitian, tetapi 4 kasus menolak karena dilakukan pengambilan sampel darah. Tidak terdapat pasien yang dieksklusi sehingga didapatkan jumlah kasus 34 pasien. Kesulitan mendapatkan kontrol yang sesuai dengan kriteria penelitian di RSUP Dr. Sardjito dan P3TKA Yogyakarta maka kontrol diambil dari anak yang tidak menderita GPP/H di SD Tegal Harjo, Depok, Sleman, Yogyakarta. Pengambilan sampel darah kontrol dan pengumpulan kuisioner dilakukan secara kolektif di sekolah, dengan petugas yang datang ke lokasi tersebut. Karakteristik dasar subyek penelitian tertera pada Tabel 1 .

Pada kelompok kasus didapatkan jenis kelamin laki-laki yang lebih banyak dibandingkan perempuan dengan proporsi 7,5:1. Hal ini masih sesuai dengan prevalensi GPP/H secara umum, rasio laki-laki

Tabel 1. Karakteristik dasar subyek penelitian

\begin{tabular}{|c|c|c|c|}
\hline Variabel & Kelompok kasus & Kelompok kontrol & $\mathrm{p}$ \\
\hline Jumlah & 34 & 35 & 0,000 \\
\hline Jenis kelamin (jumlah) & & & 0,001 \\
\hline Laki-laki & 30 & 17 & \\
\hline Perempuan & 4 & 18 & \\
\hline Umur, rata-rata $(\mathrm{SB})$ & $9.4(\mathrm{SB} 2.5)$ th & $11.0(\mathrm{SB} 0.4)$ th & 0,000 \\
\hline Pendidikan ayah & & & 0,000 \\
\hline Tamat/tidak tamat SD & 2 & 10 & \\
\hline SLTP & 1 & 4 & \\
\hline SLTA & 9 & 19 & \\
\hline Perguruan Tinggi & 22 & 2 & \\
\hline Pendidikan ibu & & & 0,000 \\
\hline Tamat/tidak tamat SD & 2 & 10 & \\
\hline SLTP & 0 & 6 & \\
\hline SLTA & 11 & 17 & \\
\hline Perguruan Tinggi & 21 & 2 & \\
\hline Kadar zink plasma, rerata $(\mathrm{SB}) \mu \mathrm{g} / \mathrm{dL}$ & $82,4(\mathrm{SB} 12,2)$ & $88,5(\mathrm{SB} 8,7)$ & 0,028 \\
\hline
\end{tabular}

Tabel 2. Hasil pemeriksaan kadar zink plasma berdasarkan kelompok GPP/H dan non GPP/H

\begin{tabular}{llll}
\hline Kadar zink & GPP/H $(+)$ & GPP/H $(-)$ & Total \\
\hline Rendah & 7 & 1 & 8 \\
Normal & 27 & 34 & 61 \\
\hline Total & 34 & 35 & 69 \\
\hline
\end{tabular}


dibanding perempuan bervariasi antara 2:1 hingga 9:1.

Distribusi hasil pemeriksaan kadar zink plasma tertera pada Tabel 2. Berdasarkan pengelompokan hasil pemeriksaan kadar zink plasma, kelompok kasus mendapatkan 7 anak yang memiliki kadar zink plasma rendah (21\%) dan 27 (79\%) normal. Sebaliknya, kelompok kontrol mendapatkan 1 anak yang memiliki kadar zink plasma rendah (3\%) dan 34 (97\%) normal. Perbandingan proporsi defisiensi zink antara kelompok GPP/H dan non GPP/H tertera pada Gambar 1.

Analisis bivariat terhadap perbedaan proporsi defisiensi zink antara kelompok GPP/H dan non GPP/H menggunakan Fisher's exact test karena berdasarkan perhitungan jumlah sel yang mempunyai nilai expected count kurang dari lima sebesar $50 \%$ sehingga syarat uji chi-square tidak terpenuhi. Didapatkan nilai $\mathrm{p}=0,028$, dengan OR 8,8 (IK95\%:1,02-76,07). Nilai probalitas dihitung dengan rumus $\mathrm{p}=\mathrm{OR} / 1+\mathrm{OR}$, dan didapatkan hasil $90 \%$.

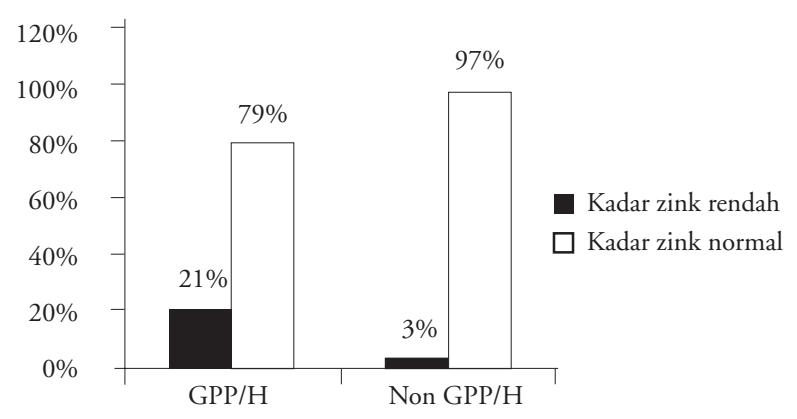

Gambar 1. Perbandingan proporsi defisiensi zink antara kelompok GPP/H dan non GPP/H

\section{Pembahasan}

Hasil penelitian kami mendukung hasil penelitian sebelumnya di berbagai negara lain yang secara konsisten mendapatkan kadar zink plasma yang lebih rendah serta proporsi defisiensi zink plasma yang lebih tinggi pada anak yang menderita GPP/H dibandingkan dengan anak yang tidak menderita GPP/H. ${ }^{9-13}$

Kekuatan hubungan antara kadar zink plasma dengan GPP/H yang dinyatakan dengan nilai OR menunjukkan bahwa anak dengan defisiensi zink mempunyai risiko 8,8 kali lipat untuk menderita GPP/H dibandingkan anak yang tidak mengalami defisiensi zink. Nilai probabilitas yang didapatkan menunjukkan bahwa peluang anak GPP/H untuk mengalami defisiensi zink 90\%.

Hasil penelitian kami hampir sama dengan hasil laporan penelitian Kiddie dkk, ${ }^{13}$ pada tahun 2010 di Kanada yang mendapatkan prevalensi defisiensi zink pada anak GPP/H delapan kali lipat dibanding kontrol. Kesamaan antara penelitian tersebut adalah dalam hal kriteria penegakan diagnosis GPP/H yang digunakan yaitu dengan DSM-IV. Sementara perbedaannya adalah Kiddie dkk menggunakan batasan defisiensi zink kurang dari $66 \mu \mathrm{g} / \mathrm{dL}$ serta menggunakan besar sampel yang lebih besar yaitu dengan melibatkan 44 kasus GPP/H. Penelitian kami menggunakan batasan defisiensi zink jika kurang dari $70 \mu \mathrm{g} / \mathrm{dL}$ dengan jumlah kasus yang lebih sedikit yaitu 34 kasus.

Penelitian kami memiliki beberapa keterbatasan. Rentang interval kepercayaan 95\% yang lebar kemungkinan disebabkan oleh karakteristik subyek yang kurang homogen. Hal tersebut dapat diakibatkan oleh teknik pengambilan sampel yang dilakukan secara non probability sampling serta tidak dilakukannya matching dalam pemilihan subyek penelitian. Kasus penelitian kami adalah semua kasus, baik baru maupun lama, karena jumlah kasus yang sedikit. Idealnya, kontrol didapatkan dari populasi yang sama dengan kasus. Namun, kami kesulitan mencari kontrol yang sesuai dengan kriteria penelitian, baik di RSUP Dr. Sardjito maupun P3TKA Yogyakarta, sehingga pengambilan sampel dilakukan di SD Tegal Harjo, Depok, Sleman, Yogyakarta. Selain itu, perbedaan proporsi defisiensi zink antara kelompok kasus dan kontrol 0,33 yang merupakan judgement peneliti pada perhitungan besar sampel dimungkinkan terlalu besar sehingga didapatkan besar sampel yang relatif sedikit.

Zink merupakan mikronutrien esensial untuk perkembangan dan fungsi sistem saraf pusat. Hubungan zink dengan GPP/H diduga melalui peran zink dalam produksi melatonin yang mengatur fungsi dopamin, yang penting dalam kejadian GPP/H. Hubungan zink dengan GPP/H diduga melalui keterlibatan zink dalam pembentukan dan pengaturan melatonin yang mengatur fungsi dopamin. ${ }^{7,8,17}$

Temuan kami memperkuat hubungan antara zink dengan GPP/H. Keterlibatan zink dalam GPP/H, apabila terbukti dapat memberikan kontribusi dalam terapi mengingat zink dapat digunakan sebagai terapi tambahan pada psikostimulan karena mempunyai harga yang murah, tersedia secara luas, relatif aman, serta diterima secara luas oleh masyarakat. 
Hal tersebut memberikan harapan baru mengingat GPP/H merupakan kondisi kesehatan yang kronis yang memerlukan pengelolaan jangka panjang dengan biaya yang mahal. ${ }^{17}$

Hasil yang kami peroleh dapat digunakan sebagai bahan pertimbangan untuk melakukan pemeriksaan kadar zink plasma pada anak yang menderita GPP/H, pertimbangan dalam penyediaan sarana untuk pemeriksaan kadar zink plasma di rumah sakit, serta sebagai bahan acuan untuk penelitian lebih lanjut. Sejauh pengetahuan penulis, penelitian ini merupakan penelitian pertama mengenai hubungan antara kadar zink plasma dengan GPP/H pada anak di Indonesia.

\section{Kesimpulan}

Proporsi defisiensi zink plasma pada anak yang menderita GPP/H lebih tinggi dibandingkan anak yang tidak menderita $\mathrm{GPP} / \mathrm{H}$, zink kemungkinan berperan dalam kejadian GPP/H.

\section{Daftar pustaka}

1. American Academy of Pediatrics, Committee on Quality Improvement, Subcommittee on Attention-Deficit/Hyperactivity Disorder. Clinical practice guideline: diagnosis and evaluation of the child with attention-deficit/hyperactivity disorder. Pediatrics 2000; 105:1158-70.

2. Spencer T, Biederman J, Wilens TE, Faraone SV. Adult with attention-deficit/hyperactivity disorder: a controversial diagnosis. J Clin Psychiatry 1998;59 Suppl 7: 59-68.

3. Kiswarjanu. Prevalensi dan faktor risiko gangguan pemusatan perhatian/hiperaktivitas pada murid taman kanak-kanak di Kotamadya Yogyakarta (tesis). Yogyakarta: Fakultas Kedokteran Universitas Gadjah Mada, 1997.

4. Saputro D, penyunting. Attention-deficit/hyperactivity disorder. Jakarta: Sagung Seto;2009.

5. Sadock BJ, Sadock VA, penyunting. Kaplan \& Sadock's synopsis of psychiatry: behavioral sciences/clinical psychiatry. Edisi ke-9. Philadelphia: Lippincott Williams \& Wilkins;2003.

6. Sinn N. Nutritional and dietary influences on attention deficit hyperactivity disorder. Nutr Rev 2008;66:558-68.

7. Black MM. Zinc deficiency and child development. Am J Clin Nutr 1998;68 Suppl 2: 464-9S.

8. Sandyk R. Zinc deficiency in attention-deficit/hyperactivity disorder. Inter J Neurosci 1990;52:239-41B.

9. Bekaroglu M, Aslan Y, Gedik Y, Deger O, Mocan H, Erduran E, Karahan C. Relationship between serum fatty acid and zinc, and attention deficit hyperactivity disorder: a research note. J Child Psychol Psychiat 1996;37:225-7.

10. Toren P, Eldar S, Sela BA. Zink deficiency in attention-deficit/ hyperactivity disorder. J Biol Phsychiatry 1996;40:1308-10.

11. Starobart-Hermelin B. The effect of deficiency of selected bioelements on hyperactivity in children with certain specified mental disorders. Ann Acad Med Stetin 1998;44:297-314.

12. Yorbik O, Ozdag MF, Olgun A, Senol MG, Bek S, Akman $S$. Potential effects of zinc on information processing in boys with attention deficit hyperactivity disorder. Prog Neuropsychopharmacol Biol Psychiatry 2008;32:662-7.

13. Kiddie JY, Weiss MD, Kitts DD, Levy-Milne R, Wasdell MB. Nutritional status of children with attention deficit hyperactivity disorder: a pilot study. Int J Pediatr 2010; 2010:767318.

14. Arnold LE, DiSilvestro RA. 2005. Zinc in attention-deficit/ hyperactivity disorder. J Child Adolesc Psychopharmacol 2005;15:619-27.

15. Akhondzadeh S, Mohammadi MR, Khademi M. Zinc sulfate as adjunct to methylphenidate for the treatment of attentiondeficit/hyperactivity disorder in children: a double-blind and randomized trial. BMC Psychiatry 2004;4:9.

16. Bilici M, Yildirim F, Kandil S. Double-blind, placebocontrolled study of zinc sulfate in the treatment of attentiondeficit/hyperactivity disorder. Prog Neuropsychopharmacol Biol Psychiatry 2004;28:181-90. 